nichrome/glass-cloth heating-element in close proximity to the inner wall. A packing of glass-wool provides efficient thermal insulation, and the whole unit is carried in a neat aluminium cradle which may either be placed directly on the bench or supported by a retort stand. Temperature is regulated by a series resistance or, more effectively on an A.c. supply, by a device named the 'Simmerstat', which gives continuous and accurate control of heat from zero to a maximum sufficient to boil liquids at $300-350^{\circ} \mathrm{C}$. Laboratory tests show that an 'Isomantle' provides a really safe and efficient method of heating liquids, particularly for operations such as routine solvent extraction. Flask breakage will be reduced to a minimum, and the large heating-area promotes uniform boiling. Deliberate efforts to induce the 'bumping' of boiling liquids were quite unsuccessful. A range of sizes from 100 to $5,000 \mathrm{ml}$. is being prepared; it is to be hoped that the manufacturers may eventually find it possible to 'tailor' jackets of other shapes for special purposes.

\section{Research in the Jewellery Industry}

THE first annual report of the Design and Research Centre for the Gold, Silver and Jewellery Industries has been issued (Goldsmiths' Hall, Foster Lane, London, E.C.2); the Centre was inaugurated on October 1, 1946. After referring briefly to the initiation of market and consumer research, the training of designers, including the provision of refresher courses and the plans for development of the library and reading room and information service, the report deals with the plans of the research section. Prof. R. S. Hutton was originally appointed honorary acting director of research, and an Advisory Research Committee has formulated a research programme and initiated investigations on tarnishresisting silver at the Metallurgical Laboratory, University of Cambridge, and on polishing processes, temper-hardened silver, coloured patina and other metal finishes at the Sir John Cass Institute, London. Dr. C. E. Garden was appointed director of research and took up his duties on June 2, 1947, and an industrial liaison officer has also been appointed. An information bulletin is being issued, and a research laboratory is being established at Goldsmiths' Hall, London.

\section{Californian Academy of Sciences}

In the annual report of the Californian Academy of Sciences for the year ending December 31, 1946, the president refers to the decision of the trustees to proceed with a campaign for raising funds which will make possible the construction of a planetarium adjacent to the Academy's buildings in Golden Gate Park. It is also planned to build an addition to the African Hall, an auditorium and additional housing to relieve the over-crowding of several of the departments. The director, Dr. R. C. Miller, refers in his report to the resumption of field-work by nine members of the Museum staff, who made eleven field trips to points ranging from Newport, Oregon, to Acapulco, Mexico, and from the seashore to the High Sierra. Many accessions to the departmental collections were made during the year, and the director reports briefly on the work of the Academy's Committee of Latent Natural Resources, established in January 1942, to organise research relating to the existing national emergency. The work of the Committee was carried on chiefly by correspondence ; the Committee has had a leavening influence far beyond the range of its immediate activities, which included the location of strategic minerals, the resources of the sea for war-time economy, black glass for mirrors for navigating instruments and tuna fisheries. The Committee is being retained as a stand-by committee for consultation on similar problems as need may arise.

\section{University News}

A CHAIR of genetics is to be established in the Faculty of Science, University of Birmingham.

Mr. Charles R. Morris, formerly fellow of Balliol College and later Under-Secretary at the Ministry of Production, has been nominated as vice-chancellor of the University of Leeds in succession to Dr. Mouat Jones, who retires on October 1, 1948.

Mr. R. L. Goodstein, lecturer in mathematies in the University of Reading, has been appointed professor of mathematics in University College, Leicester.

Dr. F. E. King, lecturer in chemistry in the University of Oxford, has been appointed Sir Jesse Boot professor of chemistry in University College, Nottingham.

\section{Announcements}

WE regret to announce the deaths of Earl Baldwin of Bewdley, K.G., P.C., F.R.S., on December 14, aged eighty; Dr. Charles Bolton, C.B.E., F.R.S., consulting physician to University College Hospital, London, on December 6, aged seventy-four ; and the Right Hon. Lord Rayleigh, F.R.S., on December 13, aged seventy-two.

Prof. A. E. MUsketr, professor of mycology and plant pathology in the Queen's University of Belfast, has been elected president for 1948 of the British Mycological Society.

The Atomic Scientists News, the journal of the Atomic Scientists' Association (limited by guarantee), issued approximately monthly, has hitherto only been available to members of the Association. To enable libraries and institutions, and other individuals who do not wish to join the Association, to obtain copies, a subscription scheme has been started. The sub. scription is $10 s$. $6 d$. a year, and further particulars are obtainable from the editor, Dr. C. H. Westcott, Physics Department, University, Edgbaston, Birmingham, 15.

THE international journal of eytology Chromosoma was founded by Dr. Hans Bauer, of the KaiserWilhelm Institut für Biologie in Berlin Dahlem, in 1939. It completed its second volume during the War, the last issue appearing in 1944. Its publication has been resumed by the Springer-Verlag, now in Vienna, with a double number (Volume 3) dated August 1947. This number contains papers by Seiler, Geitler, Le Calvez, Schrader and others on many aspects of chromosome behaviour in plants, animals and protista.

AN exhibition, "Highways of the Air", is being arranged by the Royal Geographical Society, in co-operation with the Ministry of Civil Aviation, the British Airline Corporations and the Ministry of Education, at the Society's house in Kensington Gore, London, S.W.7, during December 22-January 15 ; it will be open from 11 a.m. to 5 p.m. on weekdays (except Christmas Day and Boxing Day) free of charge. The exhibition has been planned against the background of the air-age geography and the development of civil airways. 